$H$
$\Psi$
$I$

Iberia \& the

Mediterranean World

皮

of the Middle Ages

Volume Two

TI

$<$

$\gg$

$F$

及

[H]

$\bullet$

$\mapsto$

$\mapsto$

Edited by

P.Chevedden,

D. Kagay \& P. Padilla

[I]

$\varnothing$

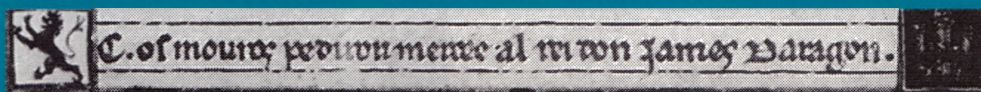

$\gg$

Z

[H]

$\gg$

Z

*

Tr

?

4

ఱ

ஜ

$\mapsto$ ?

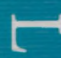

$\theta$

$\stackrel{\boxminus}{\boxminus}$

๓

$\mapsto$

II

$*$

Z

$\varangle$

[I

Z

$\varangle$

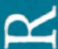

\&

디

$E$

$\mapsto$

ค

피

$\Sigma$

$\mapsto$

$\varangle$

$>$

[I

$\mapsto$

ค

디

$\Sigma$

[I]

II

$F$ 


\title{
ISLAMIC SOCIAL STRUCTURES IN MUSLIM AND CHRISTIAN VALENCIA
}

\author{
Mikel de Epalza
}

This brief essay pays tribute to Robert I. Burns, S.J., for his many contributions to the field of Islamic studies. Father Burns has explored in detail the interacting Muslim-Christian world of the thirteenthcentury Kingdom of Valencia. Notable among his many scholarly achievements is the reconstruction of a medieval Muslim society. By analyzing those elements of Islamic Valencia which survived in the post-conquest period, Father Burns has resuscitated many features of the pre-conquest society of Eastern Islamic Spain and illuminated the process by which a proud and celebrated community adapted to its new surroundings under Christian domination. ${ }^{2}$ The rich portrait which Father Burns provides of Mudejar Valencia-achieved by an exhaustive study of archival sources - is the crowning fet of his academic career and constitutes one of the monuments of medieval scholarship of this century. ${ }^{3}$

Rather than trying to summarize Burns's massive contribution in this field, abundantly reflected in his bibliography, this paper will investigate certain Islamic institutions which continued in existence after the Christian conquest. This subject has been the focus of research at the University of Alicante and of a collaborative project with Father Burns at the University of California, Los Angeles. ${ }^{4}$

${ }^{1}$ I would like to thank Dr. Donald Kagay for the translation of the Spanish original.

${ }_{2}^{2}$ See R. I. Burns, "Los mudéjares de la Valencia de las cruzadas: un capítulo olvidado de la historia islámica," SAA 1 (1984): 15-34; "Muslims in the ThirteenthCentury Realms of Aragon: Interaction and Reaction," Muslims under Latin Rule (11001300), ed. J. M. Powell (Princeton, 1990), 57-102.

${ }^{3}$ For the importance of the aljama, see M. de Epalza, "Les morisques, vus à partir des communautés mudéjares précédentes," Les Morisques et leur temps (Paris, 1984), $29-41$.

${ }^{4}$ We have both co-directed a Programme of Cooperation Research of the HispanoNorth American Committee for Scientific, Technical and Educational Development concerning "Social and Institutional Islamic Spaces in Sharq al-Andalus (Eastern Spain) before and after the Christian Conquest (Thirteenth Century)". Some conclusions of the American research partners have been published in the academic review Sharq-Al-Andalus. Estudios Arabes [SAA]. These works include: M. D. Meyerson, "The 
The political units corresponding to the Christian kingdoms of Valencia and Murcia did not always exist as such in Islamic times. Yet, the cities of both Valencia and Murcia had already assumed the role of regional capitals. As such, they would be the basic jurisdictional urban centers of the later Christian jurisdictional areas of Valencia and Murcia. Yet, in Islamic times, a part of the geographical region under examination was called Sharq al-Andalus. This term was used in pre-conquest Arabic texts to designate the eastern portion of Al-Andalus, as Muslim Spain came to be called. Along the coast, Sharq al-Andalus approximately extended from Tarragona and Tortosa to Almeria. It also included the central zones of the presentday, autonomous communities of Valencia and Murcia, as well as the Balearic Islands ("The Eastern Islands of al-Andalus"), along with some neighboring territories in Albacete, Teruel and Huesca. This maritime region was highly significant from its location: it was the "Door to al-Andalus", the entry and exit point from the Iberian Peninsula from both the Mediterranean and the Islamic East. ${ }^{5}$

Valencia, the capital city of the Christian kingdom of Valencia, progressively evolved from its early existence as a simple Christian bishopric and Visigothic fortress at the time of the Islamic Conquest. ${ }^{6}$ By the eighth century, however, it still remained only a destroyed coastal site, "the city of mud". ${ }^{7}$ Under the Umayyad dynasty, it was a capital city of a "judicial district"; in the eleventh century, it emerged as the capital of a $t \bar{a}^{\prime} i f a$ state and then as the regional center of government for Valencia and Murcia under the rule of the Almoravids.

\footnotetext{
War against Islam and the Muslims at home: the Mudejar Predicament in the Kingdom of Valencia during the Reign of Fernando 'El Católico'," 3 (1986): 10313; C. R. Backman, "Mudejars in the Criminal Laws of the Furs de Valencia under Jaime I," 4 (1987): 93-9; R. I. Burns, "Príncipe almohade y converso mudéjar: nueva documentación sobre Abu Zayd," 4 (1987): 109-22; C. Davis, "The mudejars of the Crown of Aragon in the early documents of Jaume de Conqueror (12181227)," 4 (1987): 123-9; W. C. Stalls, "Aragonese Exarici in the Twelfth Century: Their Status and Conditions of landholding," 4 (1987): 131-44; R. Zayd, "The Muslim/Mudejar in the Cantigas de Alfonso X El Sabio," 4 (1987): 145-52.

${ }^{5}$ See M. de Epalza, "Notas sobre el lingüista Ibn Sídah y la historia de Denia y su región en el siglo XI," Revista del Instituto de Estudios Alicantinos 33 (1981): 161 72; "Los beréberes y la arabización del País Valenciano," Quaderns de Filologia. Miscellània Sanchis Guamer, (Valencia, 1984), 91-100; "Costas alicantinas y costas magrebíes: El espacio marítimo musulmán según los textos árabes," SAA 3 (1986): 25-31; 4 (1987): 45-8; M. J. Rubiera, La taifa de Denia (Alicante, 1985); M. J. Rubiera and M. de Epalza, Xàtiva musulmana (segles VIII-XIII) (Xàtiva, 1987).

${ }^{6}$ M. J. Rubiera Mata, "Valencia en el pacto de Tudmir," SAA 2 (1985): 119-20.

7 M. J. Rubiera and M. de Epalza, Xàtiva, 48.
} 
It subsequently fell under the rule of the Banu-Mardanix clan (114272) and then the localized control of the Almohads. Its last ruler before Christian reconquest was the final sovereign of the BanuMardanix clan (1228-38). Valencia was thus geographically and historically predisposed to become the political capital of the new Christian kingdom created by King James I, one of the many realms under his control. Thus, all these historical vicissitudes must be kept in mind in order to understand the transition from Islamic Sharq alAndalus to the Christian Kingdom of Valencia.

With the above section, the historical framework of Sharq al-Andalus has been laid out in broad terms. For more particular details, the reader may turn to the research of other scholars. ${ }^{8}$ To clarify how this region was ruled before the Christian reconquest, we must utilize the work of a Valencian politician of the twelfth century. In the biographies he penned, Ibn-al-Abbar was quite consistent in his use of administrative terms. From his invaluable work, we have been able to classify the towns of the present-day Valencian territory into three categories: (1) two regional capitals (Valencia and Murcia); (2) several capitals of an area or 'amal (a taxation district) which were dependent on the larger cities; and (3) a number of "hamlets" (alquerias; qarya) and "small villages" (mawdi), which were dependent on the area capitals. There also existed a number of "frontier territories" (thughür), north and east of Valencia, and an assortment of "judicial districts" $(k \bar{u} r a)$, which differed from the administrative and geographical units of an earlier period. ${ }^{9}$ This "territorial arrangement" was in place during the Almohad period, just before the Christian conquest. Just how much it owed to the government of the Banu-Maradanix or to that of the Almoravids, and how much it derived from earlier administrative networks is not clear. Several works have been written about the cities of Sharq al-Andalus, claiming that these settlements were the indigenous foundation of Valencian territory. The most important of these deal with the cultural, social and administrative background of Denia $^{10}$ and Játiva, ${ }^{11}$ respectively. Other local studies, which have

${ }^{8} \mathrm{~J}$. Vallve Bermejo, "La cora de 'Tudmir' (Murcia)," Al-Andalus 27 (1972): 145-8; E. Molina Lopez, "La Cora de Tudmir segun al-'Udri (siglo XI). Aportaciónes al estudio geográfico descriptivo de SE peninsular," Cuadernos de Historia del Islam 3 (1972): 1-115.

${ }^{9}$ M. de Epalza, "L'ordenació del territori del País Valencia abans de la conquesta, segons Ibn-al-Abbar (segle XIII)," SAA 5 (1988): 41-67.

${ }_{10}$ Rubiera Mata, "La taifa de Denia".

11 Rubiera Mata and Epalza, "Xativa musulmana." 
either appeared or are under preparation, deal with the following sites: Benissa, ${ }^{12}$ Ontinyent,${ }^{13}$ Orihuela,${ }^{14}$ Petrer, ${ }^{15}$ Ondara, ${ }^{16}$ Alicante ${ }^{17}$ and others. ${ }^{18}$

In regard to the urbanization of Muslim Valencia, the elaboration of an "operative model" of the Muslim urban structure has perhaps been the most significant and promising project carried out by the joint research team of Spanish and American scholars - the most important of whom is Father Burns. ${ }^{19}$ This "operative model" is a group of elements from pre-conquest, Andalusian society, and has been compiled from the study of distinct Muslim spatial habitats. These include spaces used for military, religious, political, irrigational, commercial or craft purposes. They usually bear the same names in every Muslim settlement from the big cities to the smallest alqueria or hamlet. Numerous samples taken in modern Valencia and in other Spanish regions, which are fairly easy to locate in surviving sites, have made it possible to check the validity of this "operative model" which is itself designed to show how such spatial relationships interacted. ${ }^{20}$ By the use of the model, the patterns of life inside and outside Muslim urban sites can be better understood. ${ }^{21}$

${ }_{12}$ M. J. Rubiera Mata, M. de Epalza, et al. Mil-lenari Benissa (Benissa, 1987); M. de Epalza, "Elementos árabes en el urbanismo de Benissa," in Revista de Fiestas (Benissa, 1985).

${ }^{13}$ F. Franco Sanchez, "L'urbanisme musulmà d'Oninyent," Ontinyent. Estudis $i$ Documents 5 (1989): 23-7.

${ }_{14}$ F. Franco Suarez, Estudio de los espacios urbanos de la ciudad de Orihuela en el periodo islámico (Alicante, 1989); "El espacio del aqua en la ciudad de Orihuela en época islámica," in Aqua y poblamiento musulmán (Benissa, 1989), 33-53.

${ }^{15}$ M. de Epalza and E. Galdon, 750 anys. Civilització trencada: l'Islam valencià (Valencia, 1989), 33-4.

${ }^{16}$ M. de Epalza, "Ondara, una capital comarcal d'época àrab," in Ondara. Festes Majors (Ondara, 1990); "La estructuració comarcal de La Marina d'Ondara en època àrab (textos i tipònims)," Aigüats, (Denia, in print); "La ciutat àrab i l'estructuració dels seus topónims: el cas d'Ondara (Marina Septentrional)," in Societat d'Onomàstica. Butlleti Interior, (Barcelona, in print).

${ }_{17}$ M. de Epalza, "Alacant àrab i els seus mercats," in Revista de Fiestas (Alicante, 1989).

18 F. Franco Sanchez, "Estudio comparativo del urbanismo islámico de seis poblaciones de la Via Augusta: Sagunto/Xảtiva/Orihuela, Ontinyent/Bocairent/Beneixama," in La Ciudad Islámica, (Zaragoza, 1991), 353-75.

${ }_{19}$ M. de Epalza, "'Un modelo operativo' de urbanismo musulrnán,” $S A A 2$ (1985): 137-49; idem, "Espacios y sus funciones en la ciudad árabe," in La Ciudad Islámica, $9-30$.

${ }^{20}$ de Epalza and Galdon, 750 anys.

${ }^{21}$ M. de Epalza, "La mujer en el espacio urbano musulmán," in La mujer en AlAndalus. Reflejos históricos de su actividad y categorias sociales, ed. M. J. Viguera (MadridSevilla, 1989), 53-60. 
There have been many applications of the "operative model"22 and the results of this work have been published in the journal Sharq al-Andalus and in other monographs. ${ }^{23}$ This approach has been extremely important to archaeological investigations, since it enables one to "read" the urban plans; that is, to find the different types of spatial patterns and then to look for material remains which confirm the Islamic titles given to such areas. ${ }^{24}$ Though Muslim cities and towns were deeply affected by the Christian conquest, they still bear the imprint of their former history despite the centuries of change brought on by Christian town-planning. Sites which have lived under Christian control for five-hundred years can thus give clear evidence of what their existence under Muslim control must have been like. ${ }^{25} \mathrm{~A}$ key clue in this detective work, which is currently the subject of another international colloquium, is the structure of water flow and its use in Christian towns which, followed much the same patterns in Muslim Spain. ${ }^{26}$

When the socio-geographical spaces of pre-conquest Sharq al-Andalus

${ }^{22}$ M. de Epalza, "Etudes d'éléments urbanistiques d'Al-Andalus," Les Cahiers de Tunisie, 25 (1986): 137-8.

${ }^{23}$ M. J. Rubiera, "El vocablo árabe "sikka" en su acepción de vía y de sus posibles arabismos en la toponimia hispánica: Aceca, Seca y Villa Seca," $S A A 3$ (1986): 129 32; M. Bevia, "Bovalars, carns i rafals: la Casa del Rafalí d'Alacant," SAA 2 (1985): 115-7; idem, "Los restos arquitectónicos de la puerta de Medina Laquant," $S A A 3$ (1986): 133-45; E. Garcia Garijo, "La Alcoraya: un espacio histórico agrícola y vial," SAA 4 (1987): 153-8; A. Ferrando i Francés, "Interés històrico-geogràfic i toponímic Almodóvar d'un informe militar sobre la Serra d'Espadà (1561)," SAA 5 (1987): 153-62; A Garcia Menarguez, "Sobre la localización del topónimo Almodóvar en la desembocadura del Segura," SAA 6 (1988): 149-60; M. Garcia Sempere, "Alguns possibles topônims àrabs a la partida de Bacarot (municipi d'Alacant)," $S A A 7$ (1990): 171-4; E. Garcia Garijo, "La alcoraya alicantina y las alcorayas baleáricas," in Les Illes Orientals d'Al-Andalus (Palma de Mallorca, 1987), 165-72.

${ }^{24}$ S. Gutiérrez, "Elementos del urbanismo de la capital de Mallorca," in Les Illes, 205-24.

${ }^{25}$ M. de Epalza, "Structure des espaces dans l'urbanisme musulman et sa survivance à l'époque chrétienne en Espagne," in VII Convegno 'La Città Islamica' (Rome, 1991); idem, "Mutations des mosquées en églises et les traces de ces mutations dans le réseau urbain en Espagne," in VII Convegno 'La Città Islamica' (Rome, 1992).

${ }^{26}$ M. de Epalza, "Note sur l'eau dans les recherches sur l'urbanisme musulman en Espagne," in L'eau et la culture populaire en Méditerranée, ed. J. L. Miege, M. Perney, Ch. Villain-Gandossi (Aix-en-Provence, 1989), 23-5; F. Franco Sanchez, "Noticias de época islámica sobre inundaciones fluviales en el Baix Vinalopó y en la Vega Baja del Segura," in Avenidas fuviales e inundaciones en la cuenca del Mediterráneo (Alicante, 1989), 375-94; M. de Gea Calatayud, "Sistemas de captación y distribución de agua de probable origen árabe en Albatera y Crevillente," $S A A$ 7(1990): 175-94; idem, La fundación de Madrid y el agua en el urbanismo islámico y mediterráneo (Madrid, in print). 
are studied, it becomes clear that a specific relationship between the city and the country emerged at a very early stage, and that this occurred because of the dichotomy between the two regions - a fact emphasized by modern authors and medieval Arabic "sociologists" alike. These elements are clearly complementary, though the country was somewhat subordinated to the city. This was so because of the military authority exerted by urban authorities and the amount of land held by town residents. Indeed, the political authorities in the cities controlled the roads and defensive systems, while absentee landowners generally monopolized the agricultural wealth of the countryside. Such absenteeism signalled an urban domination which manifested itself through the control of production, profit, transport and technical innovation. The city stood as the engine of such agriculture by the demand it exerted, the technical knowledge it acquired, the transport system it imposed and the needs it dictated by the laws of variable exchange. In particular, this situation explains the specialization of some products in the history of Sharq al-Andalus (namely, saffron, esparto, silk, draught animals, etc.) and also shows the root cause of the region's flourishing agriculture and economy. ${ }^{27}$ An eleventh-century text, which has been analysed by Professor MariaJesús Rubiera, clearly reflects the state control of agricultural production, and, by extension, the domination which the city exerted over the countryside. ${ }^{28}$ In respect to the rural districts themselves, current research has centered on the alquerias or hamlets which, though existing in Christian times, had a clear Muslim provenance in the Arabic term qarya, pl. qurā. In this case as well, the Christian conquest and the provisions made by the new authorities changed the Islamic reality of Sharq al-Andalus in line with the new rulers' demands. Such a change must have come into being quickly, almost simultaneously, with the replacement of political power, since all subsequent societal changes depended on it. Such alterations have been studied with the publication of the books of "partition" (repartiment). This set of documents has to be analyzed from a particularly critical point-of-view if one wishes to draw from it a knowledge of the different societal terms of Valencia's Muslim era, even though all of these bore Arabic names..$^{29}$ As a set of cadastral documents, the repartiment attempted to

\footnotetext{
${ }^{27}$ For explanation of this structure, see Rubiera and de Epalza, Xàtiva musulmana.

${ }^{28}$ Ibid., $60-1$.

${ }^{29}$ Ibid.
} 
establish a new class of landowners and only referred to preceding Islamic societal elements in terms of the new Christian order. It must be stated, then, that the alquerias or hamlets - the qarya of Islamic times - existed only as population units; they were pueblos or small towns, which served as centers of rural population. They did not seem to act as units of production, although they did function as fiscal units, dependent on the "area capital" or 'amal. ${ }^{30}$

Another important societal norm in Islamic times, which has left numerous traces within the toponymy of Christian Valencia was that dedicated to cattle raising. These elements were maintained in such terms as albacares and rahales (raal in Spanish; rafal in Catalan). The Arabic etymology of these words also confirms their connection with cattle raising. The albacar was a vast, though secondary, enclosure in some fortresses, which was sometimes (significantly) called the "yard of the fortress" (corral de la alcazaba). Its function was mainly to pen up and hold herds which were obtained through taxation, and were thus put directly under the control of the local agent of the person who had full jurisdiction over the fortress. ${ }^{31}$ The castle's role as refuge was unusual in Islamic times, but after the Christian conquest the defensive value of this part of the fortress was reinforced. As a result of such changes, the military and livestock-maintenance function of the castle altered. The rahal was also a spatial unity which emerged from the land outside cities used for cattle raising. ${ }^{32}$ In the agricultural "irrigated and cultivated plains" (huertas), the rahales were fenced enclosures which kept cattle from grazing among and destroying crops. As a toponym, it is found at the entrance of cities or in the surrounding territory which was largely given over to pastoralism.

Agricultural land outside of cities retained the tenurial terminology. The most important of these terms were "field" (campus) or its diminutive "minor sections of autonomous land" (campello). These terms persisted into Islamic times with the Arab-Mozarab form fahs and campello. As their etymology indicates, they were large agricultural

${ }^{30}$ See above, note 9.

${ }^{31}$ M. de Epalza, "Funciones ganaderas de los albaceres en las fortalezas musulmanas," SAA 1 (1984): 47-54; M. Bevia, "L'albacar musulmà del castell d'Alacant," SAA 1 (1984): 131-40; G. Gonzalbes Gravioto, "Notas sobre las funciones del albacar en las fortificaciones del Norte de Africa," SAA 4 (1987): 199-202; J. L. Saez Castan and M. de Epalza, "Un nuevo texto mallorquín de Az-Zuhri y ganaderia en las Baleares," in Les illes, 47-53.

${ }^{32}$ M. J. Rubiera Mata, "Rafals y raales: ravals y arrabales; reals y reales," $S A A 1$ (1984): 117-22. 
spaces dependent on the city, but not at all attached to its territory, as were the huertas or vegas. The important zones of fahs in Granada, Seville, Tangiers or Tunis were well-known in medieval Arabic times. But the function of many smaller Andalusian alfás - for example, those of Alicante, Castalla, Pedreguer, Altea, Orihuela, Lerida, Huesca, Madrid, etc. - has not been thoroughly assessed. ${ }^{33}$ Though the toponomy of these places has not remained unchanged, the linguistic and geographical analysis of them enables us to better understand the spaces outside cities. ${ }^{34}$

Used to label spatial units and designate their functions, toponomy is not only enriched by the attachment of an ancient name to a certain site, but also then permits the completion of a study of the place-name's philological evolution through an analysis of its semantic load. The toponym becomes a historical document which is critically reviewed in order to mark the exact boundaries of a site as it existed in an earlier age. This place-name documentation is very often the only remaining source for getting at the history of many rural regions in Arabic times which have left no other remnants. This is the case in the area of Alicante's Marina Baixa, which has recently been successfully studied by this method. This explains the interest in gathering and studying pre-Arabic and Arabic toponyms in Valencia. ${ }^{35}$ Toponymic studies of this sort have been published in local journals, ${ }^{36}$ in the Buttleti de la Societat d'Onomàstica ${ }^{37}$ and as a

${ }^{33}$ M. de Epalza, "La dualidad Campello-Fahs en el espacio agrícola de Al-Andalus (Alicante, Castalla, Pedreguer, Madrid)," SAA 4 (1987): 159-73; idem, "El binomi àrab-mossàrab al-Fahs/El Campello, a Lleida," Societat d'Onomàstica. Butlletí Interior 35 (1989): 32.

${ }^{34}$ M. J. Rubiera and M. de Epalza, Los nombres árabes de Benidorm y su comarca (Alicante, 1985).

${ }_{35}$ J. L. Roman del Cerro and M. de Epalza, Toponimia mayor y menor de la provincia de Alicante. Listado por municipios (Alicante, 1983); A. Galmes de Fuentes, Toponimia alicantina (Oronimia) (Alicante, 1991); M. J. Rubiera and M. de Epalza, "Estat actual dels estudis de toponímia valenciana d'origen àrab," in Xe Col-loqui General de la Societat d'Onomàstica. Ier d'Onomàstica Valenciana (Valencia, 1986), 420-6.

${ }^{36}$ M. J. Rubiera Mata, "Significación de algunos topónimos árabes de Aspe," La Serranica 36 (1982): 17-8; idem, "Toponimia arábigo-Valenciana: falsos antropónimos beréberes," in Questions de Filologia. Miscel-lània Sanchis Guarner, (Valencia, 1984), 31720; idem, "El Baix Vinalopó durant l'època àrab," La Rella 6 (1988): 49-56; M. de Epalza, "Cecentaina en los textos árabes," Revista de Festes (Cocentaina, 1987); idem, "Topònims àrabs a Alacant i a Malta: Benissa d'Alacant i Benghixa de Malta," Canalobre 12/13 (1988): 196-8; idem, "La Vall d'Albaida musulmana," Estudis $i$ Documents 4 (1988): 17-24; idem, "Almúnia: el seu significat en època àrab," Antistiana (La Ràpita, 1990), 3-6.

${ }^{37}$ M. De Epalza, "Mutxamel/Muchamiel (Alacant): Origen aràbic d'aquest topònim," Buttleti 16 (1984): 15-7; idem, "Origen de Raimat," Buttletí 25 (1986): 137; idem, "El significat etimològic de Petrer: camí empedrat," Buttletí 31 (1988): 
special section of the review Sharq al-Andalus, entitled Arabic Toponymy. ${ }^{38}$ It is particularly interesting to study all the Arabic placenames in an area since they are complementary and indicate a general configuration of urban and extra-urban space. This methodology has been especially fruitful in the Catalan district of Penedes, where a general, though hitherto unknown, Arabic political and economic structure has been discovered. ${ }^{39}$ This same method has been utilized to assess geographical distribution among the rábitas of Catalonia. ${ }^{40}$

While place-names can allow us to see aspects of Arabic society, the study of water use and the structures it dictated are as important for the understanding of pre-conquest Valencia. A number of studies, emanating from conferences in Benissa, Alicante, ${ }^{41}$ Zaragoza and Madrid ${ }^{42}$ have focused on the structure of Islamic cities, as indicated by their water use. In this regard, we must start with the initial principle that every Muslim population center had certain religious water needs; that is, for the mosque and for the "hot bath" (hammām). Water was also necessary for the domestic, hygienic, craft, agricultural, and pastoral needs of the city's general populace. A stream of clear water would thus enter the city from the high ground. It would seldom reach the military citadels of the town, but would rather be diverted to the major mosque, which was located in the center of the town and then to the other mosques. It would power a number

10-1; idem, "Els mossàrabs valencians i els topònims derivats de 'kanisa' 'àrab'," in Miscellània d'homenatge a Enric Morey-Rey, 2 vols. (Montserrat, 1988), 2:149-53.

${ }^{38}$ J. M. Rubiera Mata, "Els topònims aràbigo-catalans del Baix Segura," SAA 6 (1989): 159-60; M. de Epalza, "Estudio del texto de Al-Idrisi sobre Alicante," SAA 2 (1985): 215--32; "El Cid como antropònimo ('el Leon') y como topònimo ('el Señor o Gobernador Almohade')," SAA 7 (1990): 157-74; idem, "El Cid y los musulmanes: el sistema de parias-pagas, la colaboración de Aben Galbón, el titulo de Cid-León, la posadita fortificada de Alcocer," in El Cid en el Valle de Jalón (Zaragoza, 1991), 107-25; R. Pocklington, "Notas de toponimia aràbigo-murciana," SAA 3 (1986): 11528; idem, "El emplazamiento de Iyi(h)," $S A A 4$ (1987): 175-98; idem, "Apostillas de hidronimia aràbigo-murciana," SAA 5 (1988): 153-67.

${ }^{39}$ M. de Epalza, "Toponímia àrab i estructura comarcal: El Penedés," Societat d'Onomàstica 40 (1990): 76-82; L. F. Bernabé and M. de Epalza, "Alcanar i la seva regió a l'època musulmana," in I Congrès d'Història d'Alcanar (Alcanar, 1990), 59 67.

${ }_{40}$ M. de Epalza, "Estudio Introductorio," in La rábita islámica: historia institucional (San Carles de La Ràbita, in print).

${ }^{41}$ Avenidas fuviales e inundaciones en la cuenca del Mediterráneo, ed. A. Gil Olcina and A. Morales Gil (Alicante, 1989); R. Pocklington, "Observaciones sobre el aprovechamiento del agua torrencial para la agricultura en Murcia y Lorca durante la época árabe," Murcia Musulmana, ed. F. J. Flores (Murcia, 1989), 375-83; idem, "Toponimia y sistemas de agua en Sharq-Al-Andalus," in Agua y poblamientos, 103-14.

${ }_{42}$ La fundación de Madrid y el agua en el urbanismo islámico y mediterráneo (Madrid, in print). 
of public fountains and then supply an abundant water supply for the baths at the lower end of the town. Its last application was its use by the polluting crafts (leather, pottery, dyeing, etc.), located either next to the city center or in the outskirts. Thus water in its many uses follows a relatively stable axial course for all centers of population, distributing and configuring specific spaces for its utilization. The examples of Palma de Mallorca and Madrid have been instructive in this regard. A recent monograph has dealt with baths in Arabic times in such Valencian sites as Alicante, Elx, Denia, Alcira, Valencia and Játiva. ${ }^{43}$

In addition to the study of the influence of water and other daily human needs on the shape of Muslim societies of Valencia, religion and the defense of it were also of great significance for such urbanization. The study of a common institution on the Muslim frontiers and along its coastline - the "spirituality of Islam's defense" (riba $\bar{t})$ has been favored by two factors: (1) the discovery of a group of rabitas in the Almunastir of Sharq al-Andalus (according to Yaqut AlHamawi), located in the dunes of Guadamar del Segura (Alicante) in $1984^{44}$ and (2) the International Congress which convened in Sant Carles de la Ràpita (Tarragona) in 1989 which focused on the Islamic rabita. Among the most arresting aspects of this institution are its placement on the "Islamic frontier" (thaghr) ${ }^{45}$ its link with the Christian institution of the monasterion (referred to as al-munastir in Arabic) ${ }^{46}$ and the abundance of clusters of small, though connected, mosques which came to be known as ràbitas. These correspond, in my view, to the configuration of the "cells" (cellae) in primitive Christian monasteries. Though the ràbita possessed a sense of military spirituality, it

43 Baños árabes en el Pais Valenciano, ed. M. de Epalza (Valencia, 1989).

${ }^{44}$ R. Azuar, "Primera noticia de los trabajos arqueológicos realizados en el yacimiento islámico de las dunas de Guadamar de Segura (Alicante). Una posible rábita de época califal," SAA 2 (1985): 125-36; M. de Epalza "Al-Munastir d'Ifriqiya et Al-Munastir de Sharq-Al-Andalus," in Le patrimoine andalou dans la culture arabe et espagnole. Actes du VII Colloque Universitaire Tuniso-Espagnol (Tunis, 1991), 95-106; idem, La rábita califal de las dunas de Guardamar. Cerámica. Epigrafia. Fauna. Malacofauna (Alicante, 1990).

${ }_{45}$ M. de Epalza, "El Islam aragonés, un Islam de frontera," in Turiaso. El Islam en Aragón 7 (1987): 9-21; idem, "Tortosa, un lloc estratègic a Al-Andalus," 2 (1987): 13-5; idem, "Al-Andalus et le Maghreb. Frontière de l'Islam dans la conscience musulmane, médiévale et moderne," Horizons Maghrébins 14-5 (1989): 28-32; idem, "La caiguda de València i altres caigudes d'Al-Andalus, segons l'obra en prosa d'IbnAl-Abbar," in Ibn Al-Abbar. Politic i escriptor àrab valencia (1199-1260), ed. M. de Epalza (Valencia, 1990), 19-42.

${ }^{46}$ M. de Epalza, "Constitución de rábitas en la costa de Almería: su función espiritual," in Homenaje al Padre Tapia. Almeria en su historia (Almería, 1988), 231-5. 
hardly functioned as an efficient military unit. Upcoming archaeological projects and toponimic interest in the ràbita will thus surely led to a fuller understanding of this religious and military space in Sharq al-Andalus. ${ }^{47}$

The mosque was the social nucleus which has effectively shaped the Islamic city. A full knowledge of its manifold roles is fundamental for any analysis of Valencian Muslim society. It is important to emphasize that most of the mosques in Islamic times, particularly those of the major Muslim neighborhoods or aljamas in the main towns, were transformed into churches immediately after the Christian conquest. Yet, these transformations would be carried out along guidelines that enable investigators to determine the situation and orientation of mosques, despite the changes wrought by the passing centuries. Thus, churches which where built on the sites of the old mosques, although maintaining few of the original Muslim features, did retain two original elements: (1) placement in the center of the town's road network and (2) the orientation of the right wall towards Mecca, which in Al-Andalus was S-S.E. Taking these principles into account, it must be evident that the study of churches in Valencian towns is extremely important for the reconstruction of urban structures in pre-conquest Valencia. ${ }^{48}$

While a Muslim religious strata is still to be seen in the sacred sites of Valencia's Islamic past, so the names of pre-conquest groups can be recovered from toponomy. It has already been seen that Arabic toponymy preserved in Christian Valencia is relevant as a historical source. The names of people or groups are relatively numerous among such toponyms and show the location of certain pre-conquest settlements. The dating of these Arabic names from toponymy of Christian times has great importance for Valencian historiography. Since many of these groups were of Berber origin, research has very often centered on the chronology of the Berber settlements and facilities in the region. In general, it must be concluded that the toponyms which persist in Christian documents refer to groups from immediately before the conquest. Corroborative evidence can be evinced to prove that such clusters belong to the era of full Muslim

\footnotetext{
${ }^{47}$ A. Manent, "Les rápites al Camp de Tarragona," Serra d'Or 374 (February, 1991): 114-5.

${ }^{48}$ R. Azuar Ruiz, "Las mezquitas en el ámbito rural," Actas de las II fornadas de Cultura Arabe e Islámica (1980) (Madrid, 1985), 65-72.
} 
domination. In addition, many of these toponyms were formed by the Christian conquerors themselves to give some order to their tax records. ${ }^{49}$

The reading of Burn's monographs and articles concerning the modifications of the Islamic institutions after the Christian conquest of Valencia allows us to better understand the capacity of Islam both in medieval and modern times to adapt to new circumstances. For this reason, the study of these matters is not only important because it enables us to travel through history, but it is also useful for the purpose of knowing a modern society composed of hundreds of millions of people.

${ }^{49}$ M. de Epalza, "Topònims d'origen antroponímic àrab del temps de la conquesta (Cid, Busot, Benimassot, Massoda, Benissoda)," in Societat d'Onomàstica. Butlleti Interior. XIVe Col-loqui. Alacant 1989 (Barcelona, 1991), 619-27. 


\section{IBERTA AND THE \\ MEDTTERRANEAN WORID \\ OF THE MIDDLE AGES}

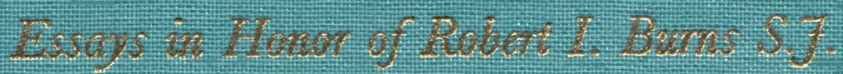

$$
\text { vorine } 2
$$

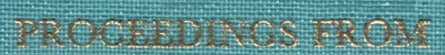

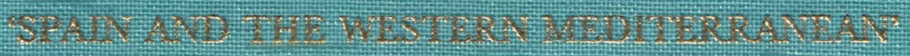

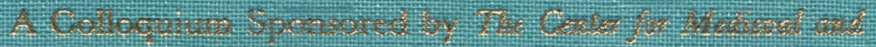

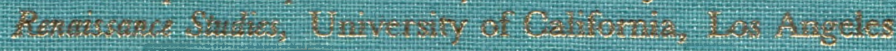

Oetanes $20 \cdot 2 \pi=303$

\section{$\operatorname{sinted~Bx~}$}

P. Canvadon:

3) J RAGAY A P. G. YADIIIA

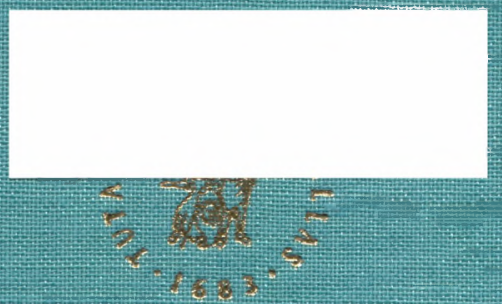




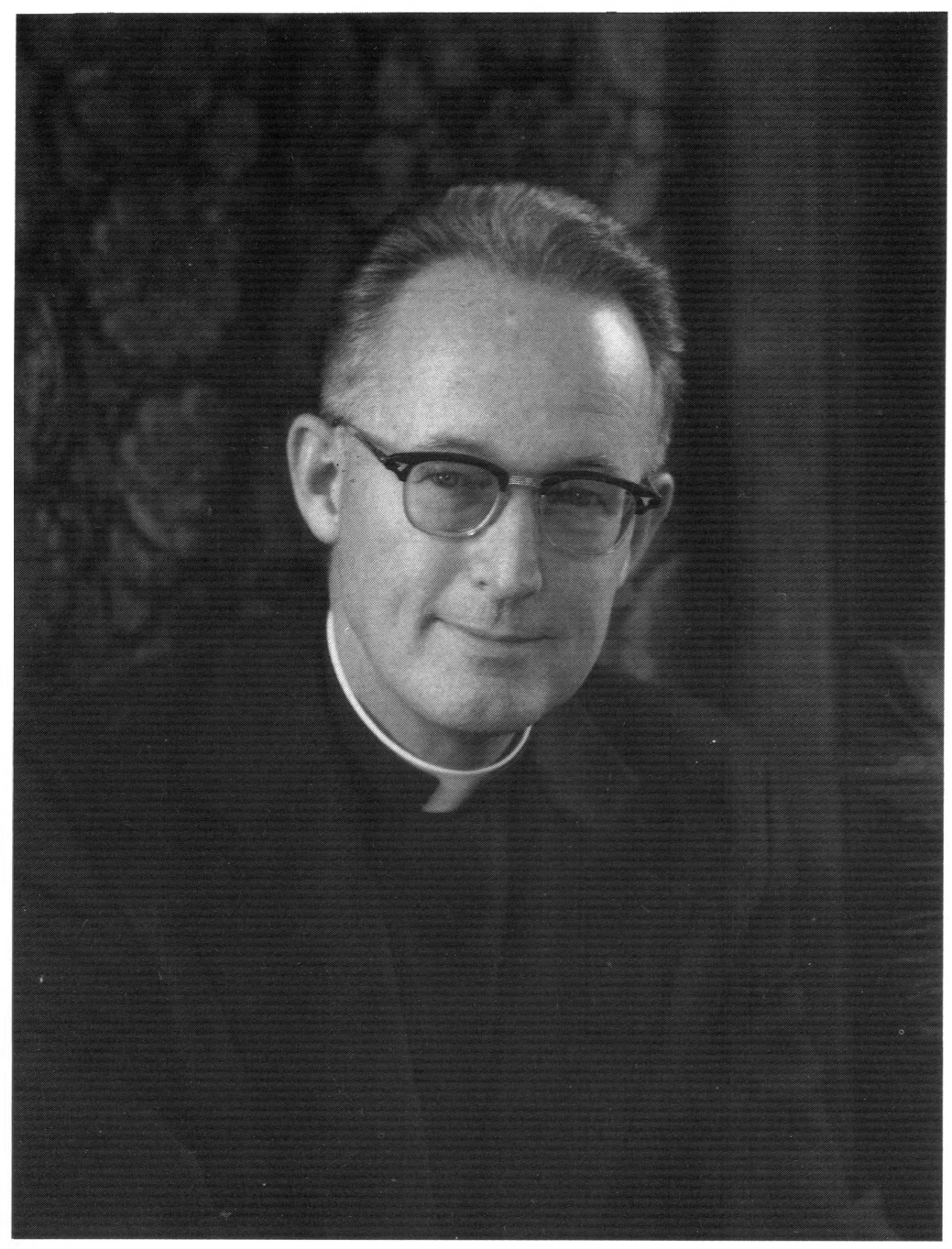

Robert I. Burns, S.J. (Photographer: Imogen Cunningham)

This photograph was taken, as I recall in 1975, and appears in the Catholic Historical Review as the presidential portrait that year or the next. This was one of Imogen Cunningham's last photographs, since she died in June 1976 at the age of ninety-three. She began her career with the great "Indians" photographer Edward S. Curtis, and was a close colleague of Ansel Adams, and herself is one of the "greats". She did this photograph largely as a favor, and very informally in her living room. 


\title{
IBERIA AND THE MEDITERRANEAN WORLD OF THE MIDDLE AGES
}

Essays in Honor of Robert I. Burns S.J.

\author{
VOLUME II \\ PROCEEDINGS FROM \\ 'SPAIN AND THE WESTERN MEDITERRANEAN' \\ A Colloquium Sponsored by The Center for Medieval and \\ Renaissance Studies, University of California, Los Angeles \\ October 26-27, 1992
}

EDITED BY

P.E. CHEVEDDEN,

D.J. KAGAY AND P. G. PADILLA

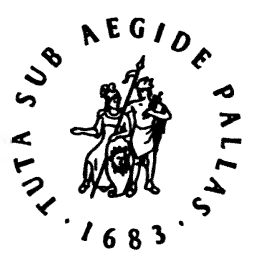

E.J. BRILL

LEIDEN $\cdot$ NEW YORK $\cdot$ KÖLN

1996 
The paper in this book meets the guidelines for permanence and durability of the Committee on Production Guidelines for Book Longevity of the Council on Library Resources.

\section{Library of Congress Cataloging-in-Publication Data}

Iberia and the Mediterranean world of the Middle Ages : studies in honor of Robert I. Burns / ed. by Larry J. Simon.

p. $\quad$ cm. - (The Medieval Mediterranean, ISSN 0928-5520 ; v. 4)

Contains contributions from presiders and commentators, as well as a selection of the presented papers, at the 27th International

Congress of Medieval Studies, assembled to pay tribute to the Rev.

Dr. Robert I. Burns, S.J., May 7-10, 1992, at Western Michigan

University in Kalamazoo, Mich.

Includes bibliographical references and index.

Contents: v. 1. Proceedings from Kalamazoo

ISBN 9004101683 (alk. paper)

1. Spain-Civilization-711-1516-Congresses. 2. Portugal- Civilization-To 1500-Congresses. 3. Mediterranean Region-

-Civilization-Congresses. 4. Civilization, Medieval-Congresses.

5. Spain-Ethnic relations - Congresses. I. Simon, Larry J.

II. Burns, Robert Ignatius. III. International Congress on Medieval

Studies (27th : Western Michigan University) IV. Series.

DP97.3.I24 1995

$946 \cdot .02-\mathrm{dc} 20$

\section{Die Deutsche Bibliothek - GIP-Einheitsaufnahme}

Iberia and the Mediterranean world of the Middle Ages : essays in honor of Robert I. Burns S.J. / ed. by P. E. Chevedden. ... Leiden ; New York ; Köln : Brill.

Bd. I hrsg. von Larry J. Simon

NE: Chevedden, Paul. E. [Hrsg.]; Simon, Larry J. [Hrsg.]; Burns, Robert

I.: Festschrift

Vol. 2. Proceedings from 'Spain and the Western

Mediterranean'. - 1996

(The medieval Mediterranean ; Vol. 8)

ISBN 90-04-10573-5

NE: GT

ISSN $09280-5520$

ISBN 9004105735

\section{Copyright 1996 by E.7. Brill, Leiden, The Netherlands}

All rights reserved. No part of this publication may be reproduced, translated, stored in a retrieval system, or transmitted in any form or by any means, electronic, mechanical, photocopying, recording or otherwise, without prior written permission from the publisher.

Authorization to photocopy items for internal or personal use is granted by E.F. Brill provided that the appropriate fees are paid directly to The Copyright

Clearance Cienter, 222 Rosewood Drive, Suite 910

Danvers MA 01923, USA.

Fees are subject to change. 


\section{CONTENTS}

List of Illustrations

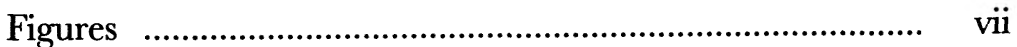

Maps ….................................................................. ix

List of Tables .................................................................... xi

List of Contributors ........................................................... x xiii

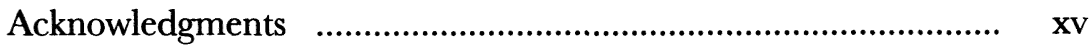

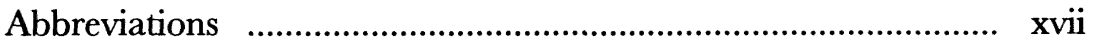

Bibliography of Robert I. Burns, S.J. ................................... xix

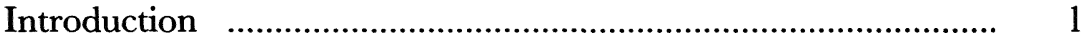

PART ONE

MAN OF TWO FRONTIERS: ROBERT I. BURNS, S.J.

R. I. Burns as Ethnologist and Historian of the Old

World and the New

LaWrence J. MaCrank

PART TWO

WARFARE AND DIPLOMACY

The Artillery of King James I the Conqueror

Paul E. Ghevedden

Army Mobilization, Royal Administration, and the

Realm in the Thirteenth-Century Crown of Aragon

Donald J. Kagay

Kings and Lords in Conflict in Late Thirteenth-Century

Castile and Aragon

Joseph F. O'Gallaghan

PART THREE

THE IAAND OF THREE RELIGIONS

The Civic Status of the Jew in Medieval Spain

Norman Roth

Conversion and Co-existence: The Franciscan

Mission in the Crown of Aragon

JiLl R. Webster 
Islamic Social Structures in Muslim and Christian Valencia

Míkel de Epalza

Berbers in Valencia: The Case of Irrigation

Thomas F. GLIGK

\section{LAY AND ECCLESIASTICAL INTERACTION}

Lay and Ecclesiastical Encounters on the Medieval Castilian Frontier

Theresa M. VANN

Sacred and Secular Politics: The Convent of Sant Pere de les Puel-les in Thirteenth-Century Barcelona

Linda A. MaMillin

Ransomers or Royal Agents: The Mercedarians and the Aragonese Grown in the Fourteenth Century

James W. Brodman

Conspiracy and Cover-up: The Order of

Montesa on Trial (1352)

ELENA LOURIE

\section{PART FIVE \\ URBAN AND GOMMERGIAL DEVELOPMENT}

The Growth of the Cities of the Crown of Aragon in the Later Middle Ages

Garmen Batlle

Commerce and the Kingdom of Majorca, 1150-1450

David Abulafia

The Transport of Muslim Slaves in

Fifteenth-Century Valencia

Paul G. Padilla

Dubrovnik and Spain: Commerce and Human Contacts,

Fourteenth-Sixteenth Centuries

BARIŠA KREKIĆ

The Spanish Kingdoms and the Wider World in

the Later Middle Ages

William D. Phillips, JR.

Bibliography

Index 